\title{
Phytoremediation of Uranium-Contaminated Soil by Perennial Ryegrass (Lolium Perenne L.) Enhanced with Citric Acid Application
}

\section{Lishan Rong}

University of South China

\section{Shiqi Zhang}

University of South China

\section{Jiali Wang}

University of South China

Shiyou Li

University of South China

\section{Shuibo Xie}

University of South China

Guohua Wang ( $\square$ wghcsu@163.com )

University of South China https://orcid.org/0000-0001-9022-5761

\section{Research Article}

Keywords: Uranium, citric acid, perennial ryegrass, ultrastructure, phytoremediation

Posted Date: August 9th, 2021

DOI: https://doi.org/10.21203/rs.3.rs-656334/v1

License: (9) (i) This work is licensed under a Creative Commons Attribution 4.0 International License. Read Full License

Version of Record: A version of this preprint was published at Environmental Science and Pollution Research on January 12th, 2022. See the published version at https://doi.org/10.1007/s11356-02218600-9. 


\section{Abstract}

Perennial ryegrass (Lolium perenne L.) was planted in uranium-contaminated soil mixture (river sand and vermiculite mixed with equal volume ratio) supplemented with different amounts of citric acid $(0,1,5$, and $10 \mathrm{mmol} / \mathrm{kg}$ ) and divided into 4 treatments (Con+0, Con +1 , Con +5 , and Con +10 ) to investigate the effects of citric acid concentrations on the remediation efficiency and enhanced mechanism of perennial ryegrass in the lab. The uranium content in the plant tissues showed that the roots were the predominant tissue for uranium accumulation, and the subcellular distributions of uranium in the root cells was in the order: cell wall fraction > cytosol fraction > organelle fraction. However, in the shoot cells the order was cell wall fraction > organelle fraction > cytosol fraction. In this study, the optimal concentration of citric acid added was $5 \mathrm{mmol} / \mathrm{kg}$, and the removal efficiency of $U$ in the shoots and roots increased by $47.37 \%$ and $30.10 \%$ respectively. The treatment with $5 \mathrm{mmol} / \mathrm{kg}$ citric acid had the highest contents of photosynthetic pigment and soluble protein, the highest activity of antioxidant enzymes, and the lowest content of MDA (malondialdehyde) and relative electrical conductivity. Moreover, the damage to the cell

ultrastructure of perennial ryegrass observed by TEM (transmission electron microscope) was significantly alleviated when $5 \mathrm{mmol} / \mathrm{kg}$ citric acid was added. All results indicate that perennial ryegrass can accumulate uranium with elevated uranium tolerance and enrichment ability when $5 \mathrm{mmol} / \mathrm{kg}$ citric acid is added under uranium stress. These results suggest that citric acid has significant effects on improving the uranium phytoremediation potential of perennial ryegrass.

\section{Introduction}

Uranium pollution in soil commonly results from uranium mining and milling activities in the nuclear industry (Sha et al. 2019). Uranium is regarded as radioactive and toxic, which poses a serious threat to the ecosystems and human health (Ye et al. 2020). Therefore, it is urgent to remediate uraniumcontaminated soil.

Phytoremediation, which uses the fixation and extraction functions of plants, can effectively remove uranium from soil and has several advantages, such as environmental friendliness, easy implementation and cost effectiveness (Burges et al. 2017, Hu et al. 2019, Li et al. 2019). It has become a hot research topic. Over the last decade, some studies have demonstrated that some plants can remediate uraniumpolluted soil with high uptake capacity, such as Indian mustard and sunflower (Laurette et al. 2012, Qi et al. 2014). However, most of these species are not suitable for commercial phytoremediation mainly because of their low annual harvestable biomass and low growth rate(Nascimento et al. 2020).

Perennial ryegrass (Lolium perenne L.) is a grass from the family Poaceae. It is native to Asia, Europe, and northern Africa but currently planted worldwide. Perennial ryegrass is widely cultivated in China as forage grass with the advantages of rapid growth, ease of management, multiple cutting times each year, and strong regeneration ability (Bin et al. 2019, Grachet \&Walker 2016). It has been proven that the enrichment of heavy metals in perennial ryegrass is highly efficient (Gunawardana et al. 2011, Zhao et al. 2018). Studies on the restorative effect of perennial ryegrass on uranium-polluted soil are so far rare 
(Gramss \&Voigt 2014, Qi et al. 2019). Thus, it is necessary to investigate whether perennial ryegrass is feasible in the process of uranium remediation and how to improve the restorative effect.

The efficiency of metal uptake by plants is associated with the bioavailability of metals of concern for the root uptake (Newete et al. 2016). Chelating agents can enhance the solubility of the metals in the contaminated soil, which increases the bioavailability for plant root uptake and translocation to the leaves of the plant(Gunawardana et al. 2011). Researchers also proposed that repeated applications of chelates could increase the bioaccumulation of uranium in M. cordata (Hu et al. 2019)..Chelating agents may be useful to chelate heavy metals in soil repair by perennial ryegrass, since they can produce a water-soluble metal-chelating agent and alter the existing form of heavy metals in soil. As an environmentally friendly chelating agent, citric acid can significantly improve the efficiency of phytoremediation and enhance the resistance of plants to heavy metals when it is added at proper concentrations (Duquène et al. 2008, Monroy-Figueroa et al. 2015). It was reported that the uraniumcitrate complex could be photodegraded in 3 days, but in the process of phytoremediation the complex existed in the soil, which could avoid the photo-degradation (Dodge \&Francis 1994). To the best of our knowledge, whether citric acid can improve the enrichment of uranium by perennial ryegrass is scarce (Liu et al. 2018). It is essential to study the enhancement of the applications of citric acid to increase the uranium bioaccumulation in perennial ryegrass.

The objective of this study is to investigate the effects of different concentrations of citric acid on the remediation efficiency of perennial ryegrass in uranium-contaminated soils. Antioxidant enzymes, including superoxide dismutase (SOD), catalase (CAT), peroxidase (POD) and glutathione reductase (GR) in perennial ryegrass may be expressed in response to various environmental stresses, which may play important roles in protecting the organelles and minimizing tissue injury (Garg \&Kaur 2013). The physiological index of perennial ryegrass and the activities of 4 types of antioxidant enzymes in perennial ryegrass were measured. The uranium enrichment ability of perennial ryegrass was determined. TEM was used to image the changes in cell ultrastructures in the phytoremediation process to gain insights into the mechanisms that perennial ryegrass utilizes to cope with the increased uranium accumulation driven by the citric acid addition to soil.

\section{Materials And Methods}

\section{Materials}

The seeds of perennial ryegrass (Lolium perenne L.) were provided by the specimen laboratory of Northwest Agriculture and Forestry University (Yangling, China). Full and uniform seeds without damage by moths were used in this study.

$\mathrm{A} \mathrm{U}(\mathrm{VI})$ stock solution of $1 \mathrm{~g} / \mathrm{L}$ was prepared by dissolving $\mathrm{UO}_{2}\left(\mathrm{NO}_{3}\right)_{2} \cdot 6 \mathrm{H}_{2} \mathrm{O}$ in $1 \mathrm{~mol} / \mathrm{L} \mathrm{HNO}$ and subsequently diluted to the desired concentration for the experiment. To monitor the contents of uranium, photosynthetic pigments, soluble proteins, and malondialdehyde (MDA) in different treatments, dithio-bis- 
nitrobenzoic acid (DTNB), Coomassie brilliant blue G-250, trichloroacetic acid (TCA), dithiothreitol (DTT), nicotinamide adenosine denucleotide hydro-phosphoric acid II (NADPH2), 2-thiobarbituric acid(TBA), 1.2ring of ethylenediaminetetraacetic acid(EDTA), and 2-(4-diethylamino-2-hydroxyphenylazo)-5bromopyridine (Br-PADAP) were used and purchased from Hongjin Chemical Co., Ltd., Hengyang, China. Unless stated otherwise, all chemical reagents were of analytical grade.

\section{Experimental design}

The experiment was performed in triplicate and the process was as follows: river sand and vermiculite were mixed with equal volume ratio to obtain the soil mixture, which was inert material to release interfering ion. Flowerpots $(150 \mathrm{~mm} \times 190 \mathrm{~mm} \times 160 \mathrm{~mm})$ containing $1.0 \mathrm{~kg}$ of the soil mixture were used. The uranyl nitrate solution was evenly sprayed into the soil mixture to obtain a uranium-soil mixture with a concentration of $5 \mathrm{mg} / \mathrm{kg}$ in a week. Then, 30 perennial ryegrass seeds were planted in each flowerpot; 25 plants with uniform growth vigor were selected one week after the seed germination. These plants were watered 1-2 times per day. Modified Hoagland's nutrient solution, a standard medium made from distilled water enriched with specified nutrients for plant growth studies, was added once a week.

Four series of experiments were performed to measure the effects of different citric acid concentrations on the efficiency and physiological characteristics of perennial ryegrass under uranium-induced stress: Con +10 (10 mmol $/ \mathrm{kg}$ citric acid), Con $+5(5 \mathrm{mmol} / \mathrm{kg}$ citric acid), Con +1 (1 mmol/ $\mathrm{kg}$ citric acid) and Con $+0(0 \mathrm{mmol} / \mathrm{kg}$ citric acid $)$. The solution $\mathrm{pH}$ of citric acid at different concentrations was adjusted to 6.5 with $\mathrm{NaOH}$ and $\mathrm{HCl}$ solutions and added to the experimental treatments a week before the harvest. Equal volumes of distilled water $(\mathrm{pH} 6.5)$ were added to the control group $(\mathrm{Con}+0)$.

After 60 days, the plants were harvested and separated into shoots (aboveground parts) and roots. The shoots were first washed with tap water and subsequently with distilled water twice. The roots were washed with abundant tap water until they were free of soil particles and subsequently washed with distilled water three times (Hu et al. 2019, Nezami et al. 2016). After being dried naturally, the shoots and roots were placed in a drying oven to be dried at a constant temperature of $80^{\circ} \mathrm{C}$ for $12 \mathrm{~h}$. Then the plant samples were ground and filtered through an 80-mesh sieve, and stored in small sample bags for later use.

The related physiological indices and uranium enrichment in the shoots and roots of perennial ryegrass were investigated in the following experiments.

\section{Analytical method}

The contents of photosynthetic pigments, soluble proteins, and MDA were determined by the ethanol extraction method, Coomassie brilliant blue method, and TBA method, respectively (Chaturvedi et al. 2015). Enzyme activities were measured as previously reported (Dixon et al. 2009).

The cellular and subcellular distributions of uranium in plant epidermal cells were observed by the 5-BrPADAP method using a Hitachi H-7650 transmission electron microscope (TEM). Briefly, the plant tissues 
were fixed with $4 \%$ glutaraldehyde, and treated with acetone dehydration $(30 \%, 50 \%, 70 \%, 80 \%, 90 \%$, and 100\%). The samples were embedded in Epon 812 and cut into 70-nm-thick slices by a Leica microtome (Leica Microsystems, Co., Ltd., Germany). A UV-vis spectrophotometer (Beijing Purkinje General Instrument Ltd., Beijing, China) was used to detect the uranium content in perennial ryegrass (Ge et al. 2020, Yang et al. 2020).

\section{Calculation formula}

The translocation factors (TFs) were calculated using Eq. (1). Where $\mathrm{C}_{\text {root }}$ is the uranium content in the root ( $\mathrm{mg} \mathrm{kg}^{-1}$ in dry weight), and $\mathrm{C}_{\text {shoot }}$ is the uranium content in the shoot ( $\mathrm{mg} \mathrm{kg}^{-1}$ in dry weight) (Al Mahmud et al. 2018, Chen et al. 2020b).

$$
\mathrm{T} F_{s}=\frac{C_{\text {shoot }}}{C_{\text {root }}}
$$

1

\section{Data analysis}

All experimental data (mean \pm SD) were analyzed with GraphPad Prism for Windows version 5.0 (GraphPad Software, La Jolla, USA).The single factor analysis of variance was performed. Values of $p<$ 0.05 were considered significant.

\section{Results And Discussion}

\section{Biomass of perennial ryegrass and uranium enrichment with different concentrations of citric acid}

The repair efficiencies on the uranium contaminated soil with perennial ryegrass were positively correlated with the biomass and uranium enrichment in the plants. The uranium concentrations in the roots of all treatments were higher than those in shoots, which demonstrates that the translocation factor of uranium from roots to shoots was less than 0.165 (Table 1). Similar findings were found by some researchers (Newete et al. 2016, Nezami et al. 2016, Nie et al. 2014). 
Table 1

Biomass changes and uranium concentrations in different tissues of perennial ryegrass in the presence of citric acid.

\begin{tabular}{|c|c|c|c|c|c|}
\hline $\begin{array}{l}\text { Treatment } \\
\text { groups }\end{array}$ & $\begin{array}{l}\text { Dry biomass } \\
\text { of } \\
\text { Shoots } \\
\text { (g/plant) }\end{array}$ & $\begin{array}{l}\text { Dry biomass } \\
\text { of } \\
\text { Roots } \\
\text { (g/plant) }\end{array}$ & $\begin{array}{l}\text { uranium in } \\
\text { shoots } \\
(\mathrm{mg} / \mathrm{kg})\end{array}$ & $\begin{array}{l}\text { uranium in } \\
\text { roots (mg/kg) }\end{array}$ & $\begin{array}{l}\text { Transfer } \\
\text { coefficient }\end{array}$ \\
\hline Con +0 & $0.718 \pm 0.010$ & $\begin{array}{l}0.262 \pm \\
0.002\end{array}$ & $\begin{array}{l}59.043 \pm \\
2.316\end{array}$ & $\begin{array}{l}528.745 \pm \\
33.033\end{array}$ & $0.112 \pm 0.011$ \\
\hline Con +1 & $0.757 \pm 0.034$ & $\begin{array}{l}0.273 \pm \\
0.009\end{array}$ & $\begin{array}{l}69.569 \pm \\
3.004\end{array}$ & $\begin{array}{l}539.371 \pm \\
15.476\end{array}$ & $0.125 \pm 0.012$ \\
\hline Con +5 & $0.843 \pm 0.020^{*}$ & $\begin{array}{l}0.294 \pm \\
0.015^{*}\end{array}$ & $\begin{array}{l}87.014 \pm \\
5.187^{\star}\end{array}$ & $\begin{array}{l}687.910 \pm \\
4.299^{\star}\end{array}$ & $0.165 \pm 0.008$ \\
\hline Con +10 & $0.748 \pm 0.010$ & $\begin{array}{l}0.284 \pm \\
0.020\end{array}$ & $\begin{array}{l}46.356 \pm \\
2.879^{*}\end{array}$ & $\begin{array}{l}440.630 \pm \\
19.358^{*}\end{array}$ & $0.105 \pm 0.010$ \\
\hline \multicolumn{6}{|c|}{ Notes: Values are given as the mean $\pm S D, n=3$. } \\
\hline$*, P<0.0$ & all & ed & 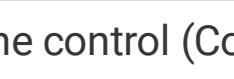 & group. & \\
\hline
\end{tabular}

The biomass and uranium enrichment in the shoots and roots of perennial ryegrass increased when citric acid was not more than $5 \mathrm{mg} / \mathrm{kg}$ (Table 1). The highest values of biomass in the shoots and roots of perennial ryegrass were detected in the Con +5 treatment, which increased by $17.41 \%(P<0.05)$ and $12.21 \%(P<0.05)$, respectively, compared to those in the control group (Con +0$)$. However, many researchers have indicated that most chelating agents added to soil increase the concentration of heavy metal ions in the soil solution, which will inhibit the plant growth and reduce biomass(Begum et al. 2012, Hseu et al. 2013, Xin et al. 2009). In several reports, the addition of organic acids in the phytoremediation process promoted the uptake of heavy metals and the biomass production (Han et al. 2016, Najeeb et al. 2009, Wang et al. 2019). In addition, the shoots and roots of the Con +5 treatment had the highest uranium concentrations, which increased by $47.37 \%(P<0.05)$ and $30.10 \%(P<0.05)$, respectively. As a result, the transfer coefficient significantly increased in the Con +5 treatment $(p<0.05)$. The reason for this may be that the applications of citric acid influenced the sorption of uranium by soil mixture, enhanced the mobility and the bioavailability of the uranium, thus increased the capability of plants to transfer the $\mathrm{U}$ from roots to shoots (Hu et al. 2019, Li et al. 2014). Introducing citric and oxalic acid treatments into the phytoremediation process can increase the ${ }^{226} \mathrm{Ra}$ uptake by a factor of 1.5 compared to the control with corn (Nezami et al. 2016). Ping Wang et al. (Wang et al. 2016) noticed that citric acid promoted the absorption of ${ }^{241} \mathrm{Am}$ by barley roots and its transport in the plants. However, a higher citric acid concentration $(10 \mathrm{mmol} / \mathrm{kg}$ ) will decrease the accumulation of uranium, although citric acid can substantially enhance the bioavailability of uranium by improving the solubilization of soil-bound uranium(Chen et al. 2020b). Thus, the toxic effects of citric acid may damage the physiological structure 
of perennial ryegrass and cause a decrease in plant biomass when the citric acid concentration reaches $10 \mathrm{mmol} / \mathrm{kg}$ (Duquène et al. 2008, Monroy-Figueroa et al. 2015).

These results suggest that $5 \mathrm{mmol} / \mathrm{kg}$ citric acid is the most effective concentration of citric acid to increase the biomass production (both in shoots and roots) and uranium enrichment in perennial ryegrass. To illustrate the strengthening mechanism of the citric acid-assisted uptake of uranium in perennial ryegrass, the effects of different concentrations of citric acid on the subcellular distribution of uranium, physiological characteristics of perennial ryegrass, activities of antioxidant system enzymes and cellular ultrastructure under uranium stress are analyzed in the following sections.

\section{Subcellular distribution of uranium in perennial ryegrass with different concentrations of citric acid}

Knowledge of the subcellular distribution of heavy metals in organisms is fundamental to understand the process of heavy-metal uptake, storage and detoxification (Nie et al. 2015). The distributions of uranium in the cell wall fraction, organelle fraction and cytosolic fraction in the shoots and roots of perennial ryegrass were further investigated. As shown in Table 2, low concentrations $(1 \mathrm{mmol} / \mathrm{kg}$ and $5 \mathrm{mmol} / \mathrm{kg})$ of citric acid could promote the enrichment of uranium in the subcellular structure of perennial ryegrass with $5 \mathrm{mmol} / \mathrm{kg}$ citric acid being the optimal concentration. In the Con +5 treatment, the uranium contents in the cell wall, organelle fraction and cytosolic fraction increased by $51.68 \%, 36.25 \%$ and $42.24 \%$ in the shoots and by $32.96 \%, 18.36 \%$ and $34.24 \%$ in the roots, respectively. In contrast, the accumulation of uranium decreased in both roots and shoots in the Con +10 treatment. These results further prove that $5 \mathrm{mmol} / \mathrm{kg}$ citric acid is the optimal concentration to enhance the enrichment of perennial ryegrass. 
Table 2

Effect of citric acid on the uranium subcellular distribution of perennial ryegrass

\begin{tabular}{|c|c|c|c|c|c|}
\hline \multirow[t]{2}{*}{. } & \multirow[t]{2}{*}{ treatments } & \multicolumn{4}{|c|}{ Uranium contents $(\mathrm{mg} / \mathrm{kg})$} \\
\hline & & cell wall fraction & organelle fraction & cytosol fraction & Total \\
\hline \multirow[t]{4}{*}{ Shoots } & Con +0 & $35.16 \pm 1.41$ & $10.40 \pm 0.66$ & $12.95 \pm 0.39$ & $59.043 \pm 2.316$ \\
\hline & Con +1 & $42.18 \pm 1.68$ & $12.04 \pm 0.49$ & $14.92 \pm 0.80$ & $69.569 \pm 3.004$ \\
\hline & Con +5 & $53.33 \pm 3.01^{*}$ & $14.17 \pm 0.78^{\star}$ & $18.415 \pm 1.25^{\star}$ & $87.014 \pm 5.187^{*}$ \\
\hline & Con +10 & $27.74 \pm 1.62$ & $8.424 \pm 0.56$ & $9.787 \pm 0.62$ & $46.356 \pm 2.879^{*}$ \\
\hline \multirow[t]{4}{*}{ roots } & Con +0 & $330.21 \pm 21.43$ & $105.29 \pm 5.65$ & $87.58 \pm 7.26$ & $528.75 \pm 33.033$ \\
\hline & Con +1 & $342.02 \pm 10.77$ & $102.09 \pm 3.75$ & $89.93 \pm 2.27$ & $539.37 \pm 15.476$ \\
\hline & Con +5 & $439.05 \pm 5.81^{*}$ & $124.62 \pm 0.84^{\star}$ & $117.57 \pm 1.65^{\star}$ & $687.91 \pm 4.299^{*}$ \\
\hline & Con +10 & $274.17 \pm 11.99$ & $86.41 \pm 3.22$ & $75.72 \pm 4.52$ & $440.63 \pm 19.358$ \\
\hline \multicolumn{6}{|c|}{ Notes: Values are given as the mean $\pm S D, n=3$} \\
\hline
\end{tabular}

The subcellular partitioning of uranium in plants reflects its internal processes during uranium accumulation, which can provide more mechanistic information about the uranium tolerance and the interaction process between uranium and perennial ryegrass (Nie et al. 2014). The distribution proportion of uranium in different parts of the same cell in roots was cell wall > organelle > cytosol, while the order in shoots was cell wall > cytosol > organelle (Table 2). These results demonstrate that a much greater part of uranium was stored in the cell wall fraction and the proportion was more than $60 \%$ in both roots and shoots, so the cell wall played an important role in the uranium tolerance. This trend is consistent with the results proposed by other researchers(Nie et al. 2015). Meanwhile, the storage capacity of uranium in the cell wall and the barrier protecting effect of cytosol improved when low concentrations $(1 \mathrm{mmol} / \mathrm{kg}$ and 5 $\mathrm{mmol} / \mathrm{kg}$ ) of citric acid were added. Consequently, all distribution proportions of uranium in the cell wall were higher than those in the control group in both roots and shoots, and all values in organelles were lower than those in the control group. However, the proportions of uranium in the cytosol of the shoots contrasted with those in the roots when low concentrations of citric acid were added, which might be closely related to the buffer capacity of the cytosol (phosphate in the cytosol bioprecipitated with uranium ) and uranium concentrations in the cell wall of roots and shoots (Pan et al. 2015). A high concentration $(10 \mathrm{mmol} / \mathrm{kg})$ of citric acid decreased the accumulation of uranium in roots and shoots, and the distribution trends of uranium in different parts were consistent with those in the $5 \mathrm{mmol} / \mathrm{kg}$ citric acid treatment.

\section{Physiological characteristics of perennial ryegrass with different concentrations of citric acid}


Photosynthetic pigment content, which is a direct indicator of plant photosynthesis, can be used as a tolerance criterion for heavy metals in plants(Sebastian \&Prasad 2018). In order to eliminate the interference from other ions, As shown in Fig. 1A, $5 \mathrm{mmol} / \mathrm{kg}$ citric acid enhanced the photosynthesis of perennial ryegrass, which indicates an elevated tolerance to uranium. This phenomenon was also reported in a previous study (Chen et al. 2020b). However, the enhanced effects on the uranium tolerance of perennial ryegrass with $1 \mathrm{mmol} / \mathrm{kg}$ or $10 \mathrm{mmol} / \mathrm{kg}$ citric acid were not significant compared to the 5$\mathrm{mmol} / \mathrm{kg}$ citric acid treatment. Compared to the control group (Con +0$)$, the levels of chlorophyll-a (chl-a), chlorophyll-b (chl-b), and carotenoids in the $5-\mathrm{mmol} / \mathrm{kg}$ treatment (Con +5$)$ increased by $28.29 \%, 44.16 \%$, and $28.99 \%$ respectively. In contrast, the levels of chl-a, chl-b, and carotenoids did not significantly change in the Con +1 and Con +10 treatments $(p>0.05)$. The data indicate that the chl-b content in perennial ryegrass is significantly correlated with the citric acid concentration $(p<0.05)$. However, the chla and carotenoid levels were not significantly correlated with the citric acid concentration $(p>0.05)$. Further research is required to elucidate the enhanced mechanisms of the associations among the pigment contents, citric acid concentrations, and uranium tolerance of perennial ryegrass.

The permeability of the cell membrane reportedly increases when it is exposed to uranium, which causes the leakage of intracellular electrolytes and increases the relative electric conductivity (REC) (Dai et al. 2017). Simultaneously, the peroxidation of cell membrane lipids generates MDA, which reacts with proteins and nucleic acids, and the cell function is affected (Chen et al. 2020a, Khair et al. 2020). Therefore, the relative electrical conductivity, MDA content and soluble protein content which are major indices of the cell membrane permeability, appear to be closely related to the $U$ tolerance. As shown in Figs. $1 \mathrm{~B}, \mathrm{C}$ and $\mathrm{D}$, the root conductivity and MDA content were generally higher than those in the leaves. Thus, the degree of damage to the root cells in perennial ryegrass was more severe than that to the leaf cells. Meanwhile, the Con +5 treatment had the lowest relative electrical conductivity and MDA. The mean electrical conductivity values of the shoots and roots in the Con +5 treatment decreased by $20.19 \%$ ( $p<$ 0.05 ) and $20.26 \%(p<0.05)$ compared to the control group (Fig. 1B). Similarly, the mean MDA values of the shoots and roots in the Con +5 treatment decreased by $22.16 \%(p<0.05)$ and $23.63 \%(p<0.05)$ compared to the control group (Fig. 1C). Thus, citric acid ( $5 \mathrm{mmol} / \mathrm{kg}$ ) can significantly decrease the electrical conductivity and MDA in the shoots and roots of plants, which are negatively correlated with the uranium tolerance (Li et al. 2019).

Furthermore, the contents of soluble proteins in plants of all treatments were investigated. As illustrated in Fig. 1D, the contents of soluble proteins in the plant shoots of the Con +1 , Con +5 , and Con +10 treatments were 1.31-, 1.90-, and 1.49-fold higher than those in the control group. The contents of soluble proteins in the plant roots of the Con +1 , Con +5 , and Con +10 treatments were 1.03-, 1.39-, and 1.05-fold higher than those in the control group. All contents of soluble protein in the shoots and roots of plants in the Con +5 treatment were higher than those in the Con +1 and Con +10 treatments, which suggests that citric acid ( $5 \mathrm{mmol} / \mathrm{kg}$ ) can significantly increase the contents of soluble proteins in the shoots and roots of plants $(P<0.05)$. 
All of these results reveal that $5 \mathrm{mmol} / \mathrm{kg}$ citric acid can alleviate the cell damage of perennial ryegrass exposed to uranium stress.

\section{Effects of different citric acid concentrations on the activities of antioxidant system enzymes}

As shown in Fig. 2, all activities of POD (Fig. 2A), SOD (Fig. 2B), CAT(Fig. 2C), and GR(Fig. 2D) in the shoots and roots increased with different concentrations of citric acid in the Con +1 , Con +5 , and Con + 10 treatments compared to those in the control group. However, only the values in the Con +5 treatment were significantly more efficiently affected than those in the control group $(P<0.05)$. Therefore, 5 $\mathrm{mmol} / \mathrm{kg}$ was the most effective concentration of citric acid to enhance the activities of the four types of antioxidant enzymes in perennial ryegrass.

When subjected to uranium stress, plant cells may produce $\mathrm{H}_{2} \mathrm{O}_{2}$ to reduce the fixation efficiency of $\mathrm{CO}_{2}$ in cells, while $\mathrm{H}_{2} \mathrm{O}_{2}$ (Haber-Weiss) combines with superoxide anion $\left(\mathrm{O}^{2-}\right)$ to generate reactive oxygen species (ROS), which is harmful to the plants. In plant cells, antioxidant enzymes such as POD, SOD, CAT, and GR can be used to resist the harmfulness of ROS. SOD can transform $\mathrm{O}_{2}$ - into $\mathrm{H}_{2} \mathrm{O}_{2}$ (Slomka et al. 2008), which effectively resists the generation of ROS in cells. CAT reacts with high concentrations of POD and POD reacts with low concentrations of $\mathrm{H}_{2} \mathrm{O}_{2}$. The two reactions interactively transform $\mathrm{O}_{2}$ - into $\mathrm{H}_{2} \mathrm{O}$ and $\mathrm{H}_{2} \mathrm{O}_{2}$ (Geebelen et al. 2002, Smeets et al. 2005). GR catalyzes the transformation of oxidized glutathione into glutathione to resist the generation of ROS in combination with SOD (Slomka et al. 2008).

Our results indicate that all changes in activities of POD, SOD, CAT, and GR in the shoots and roots of perennial ryegrass were significantly correlated with the citric acid concentration $(P<0.05)$, which suggests that the addition of the chelating agent citric acid can enhance the antioxidant enzyme activity of perennial ryegrass. Therefore, the chelating agent citric acid can contribute to plant adaptation to uranium-contaminated soil environments. Our results in this study are consistent with some previous reports (Gajewska \&Sklodowska 2007, Slomka et al. 2008).

\section{Cellular ultrastructure with different citric acid concentrations}

According to the above results, the cellular ultrastructure was affected by the con +5 treatment. As shown in Fig. 3A, the cellular ultrastructure of shoots in perennial ryegrass was unchanged with normal mitochondria and an evenly distributed matrix in the control group. Chloroplasts were obviously observed, normally surrounded by a double membrane. In contrast, the cell structure of plant shoots with $5 \mathrm{mg} / \mathrm{kg}$ uranium was changed with a significantly reduced number of mitochondria, expanded chloroplasts, damaged cell walls and disrupted double chloroplast membranes (Fig. 3B).In the treatment with 5 $\mathrm{mmol} / \mathrm{kg}$ citric acid (Fig. 3C), the cell structure of plant shoots partially returned normal. Interestingly, in plant shoot cells, the mitochondrial number increased, the chloroplast was seemingly normal, and the cell wall was observable. The effects of uranium and citric acid on the cell structure in the plant roots were 
identical to those in the plant shoots. In the treatment without uranium, the cell structure of the plant roots was normal (Fig. 3D). The cell structure was partly disrupted by the treatment with $5 \mathrm{mg} / \mathrm{kg}$ uranium (Fig. 3E). The effect of uranium on the cell ultrastructure was partially alleviated when 5 $\mathrm{mmol} / \mathrm{kg}$ citric acid was added (Fig. 3F).

In summary, these results suggest that citric acid $(5 \mathrm{mmol} / \mathrm{kg})$ can attenuate uranium-induced damage to perennial ryegrass.

\section{Conclusions}

This study shows that perennial ryegrass can strongly enrich uranium in plants, and $5 \mathrm{mmol} / \mathrm{kg}$ citric acid can significantly increase the enrichment and transportation of uranium in perennial ryegrass. The activities of antioxidant enzymes (POD, CAT, SOD, GR) are up-regulated with $5 \mathrm{mmol} / \mathrm{kg}$ citric acid. The relative electrical conductivity and MDA content of perennial ryegrass decrease, and the contents of photosynthetic pigment and soluble protein increase with $5 \mathrm{mmol} / \mathrm{kg}$ citric acid. TEM images of the ultrastructure in roots and shoot cells of perennial ryegrass prove that $5 \mathrm{mmol} / \mathrm{kg}$ citric acid can lighten the damage degree under uranium stress. It is a promising bioremediation strategy for uraniumcontaminated soil.

\section{Declarations}

Authors' contributions All authors contributed to the study conception and design. Method implementation and optimization, analysis, and data evaluation were performed by Lishan Rong and Shiqi Zhang. The first draft of the manuscript was written by Shiyou Li and Guohua Wang. Shuibo Xie, Jiali Wang and Guohua Wang commented on previous versions of the manuscript. All authors read and approved the final submitted manuscript

Funding This work was financially supported by the National Natural Science Foundation of China (11475080, 51904155), Education Department Fund of Hunan Province of China (19C1588) and Hengyang's Science and Technology Planning Projects (2018KJ130).

Data availability The datasets generated and/or analyzed during the current study are property of Lishan Rong. (University of South China, China); they are available from the corresponding author who will inform Lishan Rong that the data will be released on reasonable request

\section{Compliance with ethical standards}

Conflict of interest The authors declare that they have no conflict of interest

Ethical approval Not applicable

Consent to participate Not applicable 
Consent to publish Not applicable

Disclaimer The sponsors did not influence either the study design, analysis and interpretation of data, or the decision to submit the article for publication

\section{References}

1. Al Mahmud J, Hasanuzzaman M, Nahar K, Bhuyan MHMB, Fujita M (2018): Insights into citric acidinduced cadmium tolerance and phytoremediation in Brassica juncea L.: Coordinated functions of metal chelation, antioxidant defense and glyoxalase systems. Ecotox Environ Safe 147, 990-1001

2. Begum ZA, Rahman IMM, Tate Y, Sawai H, Maki T, Hasegawa H (2012): Remediation of toxic metal contaminated soil by washing with biodegradable aminopolycarboxylate chelants. Chemosphere 87, $1161-1170$

3. Bin X, Guohui Y, Hui L, Zheni X, Wuwu W, Jing Z, Bingru H (2019): Knockdown of STAYGREEN in Perennial Ryegrass (Lolium perenne L.) Leads to Transcriptomic Alterations Related to Suppressed Leaf Senescence and Improved Forage Quality. Plant and Cell Physiology 60, 202-212

4. Burges A, Epelde L, Blanco FJM, Becerril JM, Garbisu C (2017): Ecosystem services and plant physiological status during endophyte-assisted phytoremediation of metal contaminated soil. Science of the Total Environment 584-585, 329-338

5. Chaturvedi N, Dhal NK, Patra HK (2015): EDTA and citric acid-mediated phytoextraction of heavy metals from iron ore tailings using Andrographis paniculata: a comparative study. Int J Min Reclam Env 29, 33-46

6. Chen L, Yang JY, Wang D (2020a): Phytoremediation of uranium and cadmium contaminated soils by sunflower (Helianthus annuus L.) enhanced with biodegradable chelating agents. J Clean Prod 263

7. Chen L, Yang JY, Wang D (2020b): Phytoremediation of uranium and cadmium contaminated soils by sunflower ( Helianthus annuus L.) enhanced with biodegradable chelating agents. J Clean Prod 263,121491

8. Dai H, Wei S, Twardowska I, Han R, Xu L (2017): Hyperaccumulating potential of Bidens pilosa L. for $\mathrm{Cd}$ and elucidation of its translocation behavior based on cell membrane permeability. Environmental Science \& Pollution Research 24, 23161-23167

9. Dixon, P. D, Hawkins, Timothy, Hussey, J. P, Edwards, Robert (2009): Enzyme activities and subcellular localization of members of the Arabidopsis glutathione transferase superfamily. Journal of Experimental Botany 60, 1207-1218

10. Dodge CJ, Francis AJ (1994): Photodegradation of uranium-citrate complex with uranium recovery. Environmental Science \& Technology 28, 1300-6

11. Duquène L, Tack F, Meers E, Baeten J, Wannijn J, Vandenhove H (2008): Effect of biodegradable amendments on uranium solubility in contaminated soils. science of the total environment 391, 2633 
12. Gajewska E, Sklodowska M (2007): Effect of nickel on ROS content and antioxidative enzyme activities in wheat leaves. Biometals 20, 27-36

13. Garg N, Kaur H (2013): Response of Antioxidant Enzymes, Phytochelatins and Glutathione Production Towards Cd and Zn Stresses in Cajanus cajan (L.) Millsp. Genotypes Colonized by Arbuscular Mycorrhizal Fungi. Journal of Agronomy \& Crop Science 199, 118-133

14. Ge YJ, He ZQ, Wu J, Wang GH, Xie SB, Liu JX (2020): Manganese ferrite/porous graphite carbon nitride composites for $\mathrm{U}(\mathrm{VI})$ adsorption from aqueous solutions. J Radioanal Nucl Ch 326, 157-171

15. Geebelen W, Vangronsveld J, Adriano DC, Poucke LCV, Clijsters H (2002): Effects of Pb-EDTA and EDTA on Oxidative Stress Reactions and Mineral Uptake in Phaseolus vulgaris. Physiol Plant 115, 377-384

16. Grachet NG, Walker NR (2016): First Report of Brown Ring Patch Caused by Waitea circinata on Perennial Ryegrass (Lolium perenne) in Oklahoma. Plant Dis 100, 855-855

17. Gramss G, Voigt KD (2014): Forage and rangeland plants from uranium mine soils: long-term hazard to herbivores and livestock? Environ Geochem HIth 36, 441-452

18. Gunawardana B, Singhal N, Johnson A (2011): Effects of Amendments on Copper, Cadmium, and Lead Phytoextraction by Lolium Perenne from Multiple-Metal Contaminated Solution. International Journal of Phytoremediation 13, 215-232

19. Han Y, Zhang L, Gu J, Zhao J, Fu J (2016): Citric acid and EDTA on the growth, photosynthetic properties and heavy metal accumulation of Iris halophila Pall. cultivated in $\mathrm{Pb}$ mine tailings. International Biodeterioration \& Biodegradation 128, 15-21

20. Hseu ZY, Jien SH, Wang SH, Deng HW (2013): Using EDDS and NTA for enhanced phytoextraction of Cd by water spinach. Journal of Environmental Management 117, 58-64

21. Hu N, Lang T, Ding DX, Hu JS, Li CW, Zhang H, Li GY (2019): Enhancement of repeated applications of chelates on phytoremediation of uranium contaminated soil by Macleaya cordata. Journal Of Environmental Radioactivity 199, 58-65

22. Khair KU, Farid M, Ashraf U, Zubair M, Rizwan M, Farid S, Ishaq HK, Iftikhar U, Ali S (2020): Citric acid enhanced phytoextraction of nickel ( $\mathrm{Ni})$ and alleviate Mentha piperita (L.) from Ni-induced physiological and biochemical damages. Environmental Science and Pollution Research 5, 1-13

23. Laurette J, Larue C, Mariet C, Brisset F, Khodja H, Bourguignon J, Carriere M (2012): Influence of uranium speciation on its accumulation and translocation in three plant species: Oilseed rape, sunflower and wheat. Environ Exp Bot 77, 96-107

24. Li C, Wang ML, Luo XG, Liang LL, Han X, Lin XY (2019): Accumulation and effects of uranium on aquatic macrophyte Nymphaea tetragona Georgi: Potential application to phytoremediation and environmental monitoring. Journal Of Environmental Radioactivity 198, 43-49

25. Li CW, Hu N, Ding DX, Hu JS, Wang YD (2014): Phytoextraction of uranium from contaminated soil by Macleaya cordata before and after application of EDDS and CA. Environ Sci Pollut Res Int 22, 6155-6163 
26. Liu XY, Cao LY, Zhang XY, Chen J, Huo ZH, Mao Y (2018): Influence of alkyl polyglucoside, citric acid, and nitrilotriacetic acid on phytoremediation in pyrene-Pb co-contaminated soils. International Journal Of Phytoremediation 20, 1055-1061

27. Monroy-Figueroa J, Mendoza-Castillo DI, Bonilla-Petriciolet A, Perez-Cruz MA (2015): Chemical modification of Byrsonima crassifolia with citric acid for the competitive sorption of heavy metals from water. Int J Environ Sci Te 12, 2867-2880

28. Najeeb U, Xu L, Ali S, Jilani G, Gong HJ, Shen WQ, Zhou WJ (2009): Citric acid enhances the phytoextraction of manganese and plant growth by alleviating the ultrastructural damages in Juncus effusus L. J Hazard Mater 170, 1156-1163

29. Nascimento CWAd, Hesterberg D, Tappero R, Nicholas S, Silva FBVd (2020): Citric acid-assisted accumulation of $\mathrm{Ni}$ and other metals by Odontarrhena muralis : Implications for phytoextraction and metal foliar distribution assessed by $\mu$-SXRF. Environmental Pollution 260, 114025

30. Newete SW, Erasmus BFN, Weiersbye IM, Byrne MJ (2016): Sequestration of precious and pollutant metals in biomass of cultured water hyacinth (Eichhornia crassipes). Environmental Science And Pollution Research 23, 20805-20818

31. Nezami S, Malakouti MJ, Samani AB, Maragheh MG (2016): Effect of low molecular weight organic acids on the uptake of Ra-226 by corn (Zea mays L.) in a region of high natural radioactivity in Ramsar-Iran. Journal Of Environmental Radioactivity 164, 145-150

32. Nie X, Dong F, Liu N, Liu M, Zhang W, Sun S, Yang J (2014): An investigation on the subcellular distribution and compartmentalization of uranium in Phaseolus vulgaris L. Journal of Radioanalytical \& Nuclear Chemistry 299, 1351-1357

33. Nie X, Dong F, Liu N, Liu M, Zhang D, Kang W, Sun S, Zhang W, Yang J (2015): Subcellular distribution of uranium in the roots of Spirodela punctata and surface interactions. Applied Surface Science 347, $122-130$

34. Pan X, Chen Z, Chen F, Cheng Y, Lin Z, Guan X (2015): The mechanism of uranium transformation from $\mathrm{U}(\mathrm{VI})$ into nano-uramphite by two indigenous Bacillus thuringiensis strains. Journal of Hazardous Materials 297, 313-319

35. Qi FF, Zha ZY, Du L, Feng XJ, Wang DN, Zhang D, Fang ZD, Ma LJ, Jin YD, Xia CQ (2014): Impact of mixed low-molecular-weight organic acids on uranium accumulation and distribution in a variant of mustard (Brassica juncea var. tumida). J Radioanal Nucl Ch 302, 149-159

36. Qi X, Hao XC, Chen XM, Xiao SQ, Chen SL, Luo XG, Wang SQ, Tian J, Wang D, Tang YL (2019): Integrated phytoremediation system for uranium-contaminated soils by adding a plant growth promoting bacterial mixture and mowing grass. J Soil Sediment 19, 1799-1808

37. Sebastian A, Prasad MNV (2018): Exogenous citrate and malate alleviate cadmium stress in Oryza sativa L.: Probing role of cadmium localization and iron nutrition. Ecotoxicology \& Environmental Safety $166,215-222$

38. Sha YH, Hu N, Wang YD, Chen SY, Zou C, Dai ZR, Zhang H, Ding DX (2019): Enhanced phytoremediation of uranium contaminated soil by artificially constructed plant community plots. 
Journal Of Environmental Radioactivity 208

39. Slomka A, Libik-Konieczny M, Kuta E, Miszalski Z (2008): Metalliferous and non-metalliferous populations of Viola tricolor represent similar mode of antioxidative response. J Plant Physiol 165, 1610-1619

40. Smeets K, Cuypers A, Lambrechts A, Semane B, Hoet P, Laere AV, Vangronsveld J (2005): Induction of oxidative stress and antioxidative mechanisms in Phaseolus vulgaris after $\mathrm{Cd}$ application. Plant Physiol Biochem 43, 437-444

41. Wang K, Liu YH, Song ZG, Wang D, Qiu WW (2019): Chelator complexes enhanced Amaranthus hypochondriacus L. phytoremediation efficiency in Cd-contaminated soils. Chemosphere 237

42. Wang P, Du L, Tan Z, Su R, Li T (2016): Effects of Organic Acids and Sylvite on Phytoextraction of 241 Am Contaminated Soil. Bulletin of Environmental Contamination \& Toxicology 98, 1-6

43. Xin W, Ying W, Mahmood Q, Islam E, Jin X, Li T, Yang X, Dan L (2009): The effect of EDDS addition on the phytoextraction efficiency from $\mathrm{Pb}$ contaminated soil by Sedum alfredii Hance. J Hazard Mater $168,530-535$

44. Yang F, Xie SB, Wang GH, Yu CW, Liu HY, Liu YJ (2020): Investigation of a modified metal-organic framework UiO-66 with nanoscale zero-valent iron for removal of uranium (VI) from aqueous solution. Environmental Science And Pollution Research 27, 20246-20258

45. Ye TZ, Liu ZR, Cai ZW (2020): Adsorption of uranium(VI) from aqueous solution by novel dibutyl imide chelating resin. J Radioanal Nucl Ch 323, 223-232

46. Zhao YP, Cui JL, Chan TS, Dong JC, Chen DL, Li XD (2018): Role of chelant on Cu distribution and speciation in Lolium multiflorum by synchrotron techniques. Science Of the Total Environment 621, 772-781

\section{Figures}


Fig. 1

A

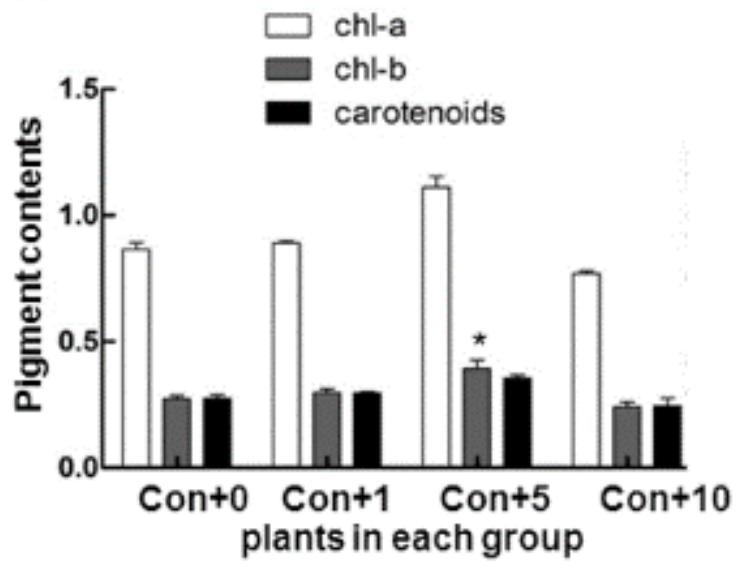

C

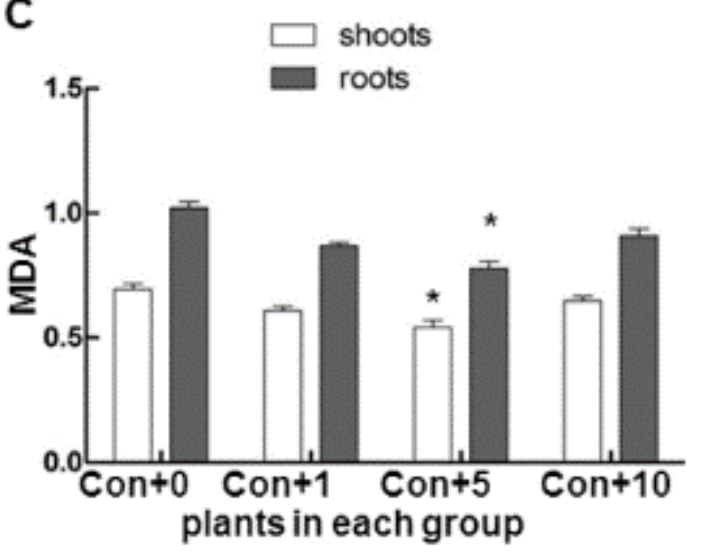

B
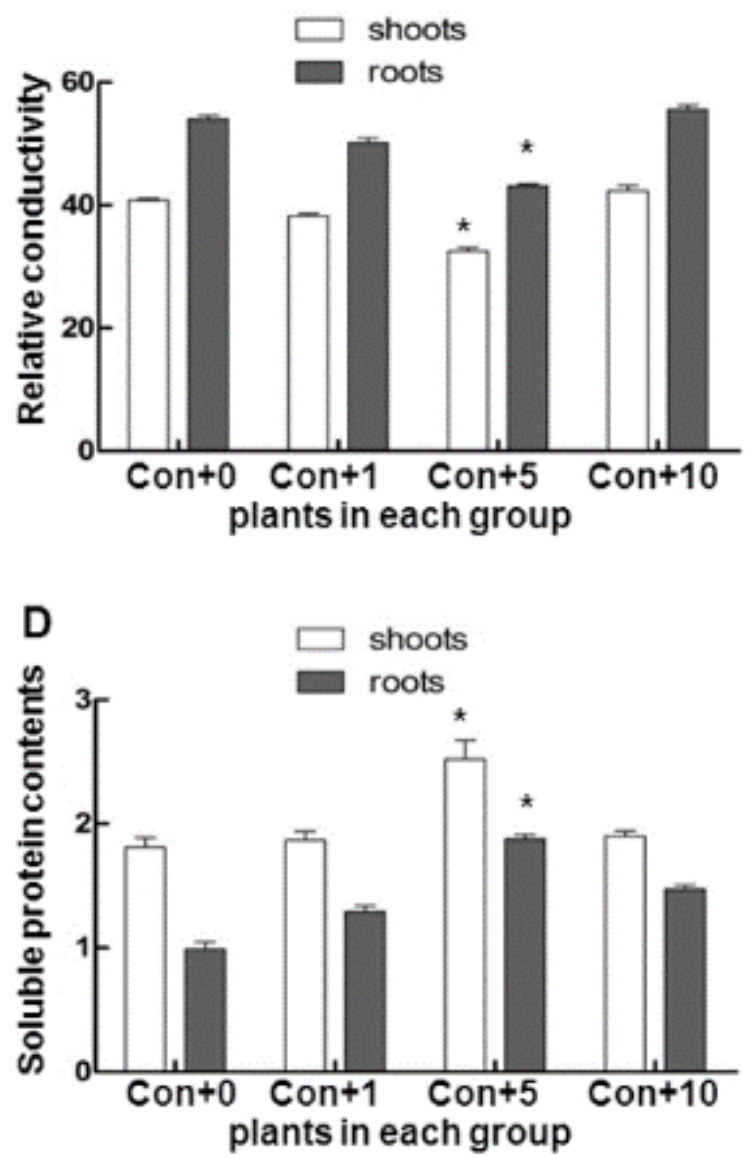

Figure 1

Measurements of the physiological and biochemical indices of perennial ryegrass (A) Photosynthetic pigment content $(\mathrm{mg} / \mathrm{g}, \mathrm{FW})$ in perennial ryegrass with added citric acid; (B) Relative conductivity (\%) in perennial ryegrass with added citric acid; (C) MDA content (mg/g, FW) in perennial ryegrass with added citric acid; (D) Soluble protein content (mg/g, FW) in perennial ryegrass with added citric acid. FW: plant fresh weight. 
Fig. 2

A

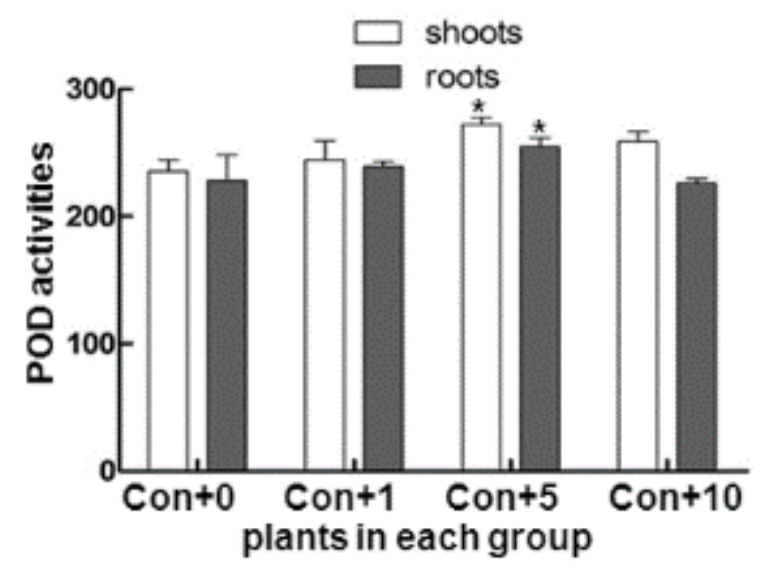

C

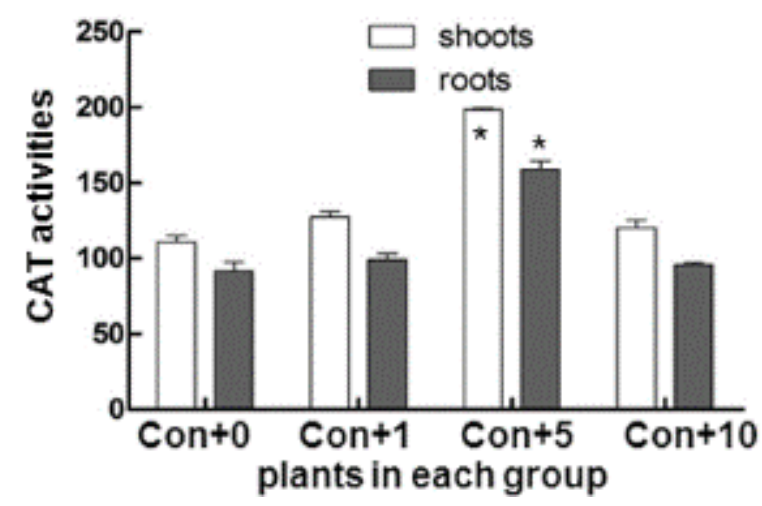

B

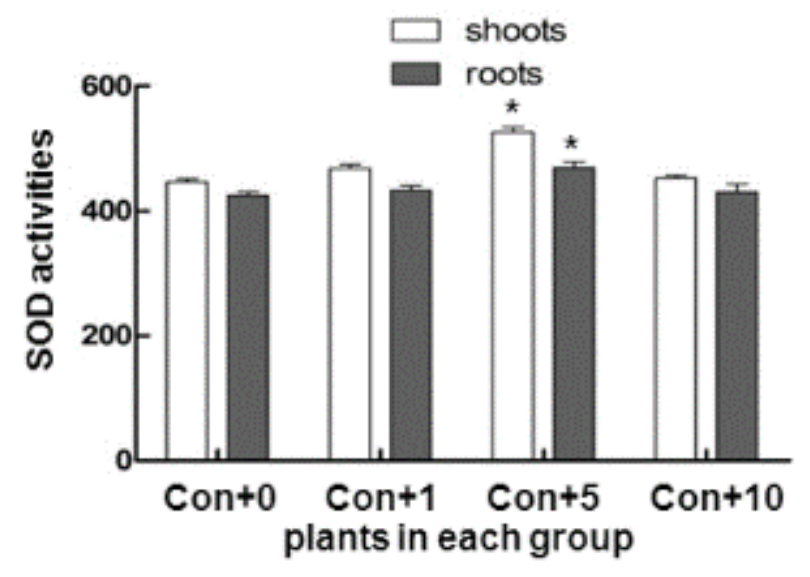

D

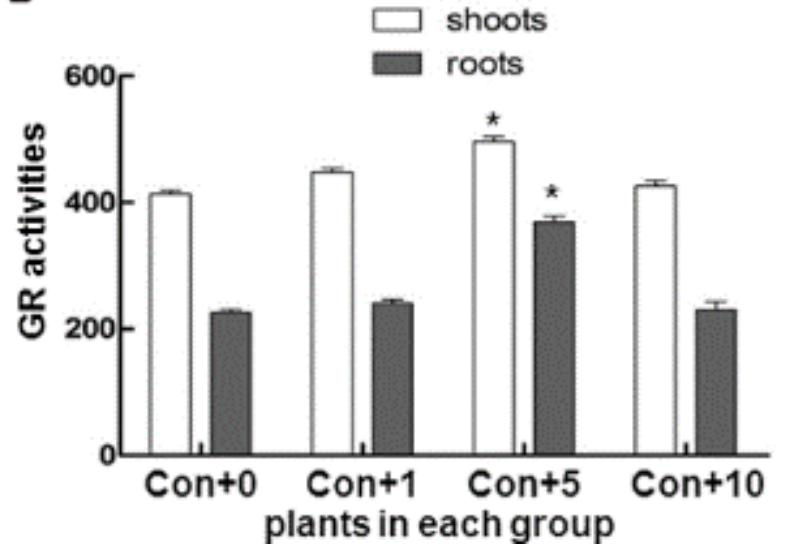

Figure 2

Detection of activities of antioxidant system enzymes in perennial ryegrass. (A) The activity (Ug-1 min-1) of POD in perennial ryegrass with citric acid; (B) The activity (Ug-1) of SOD in perennial ryegrass with citric acid; (C) The activity (Ug-1 min-1) of CAT in perennial ryegrass with citric acid; (D) The activity (Ug$1 \mathrm{~min}-1)$ of GR in perennial ryegrass with citric acid. 
Fig. 3

A

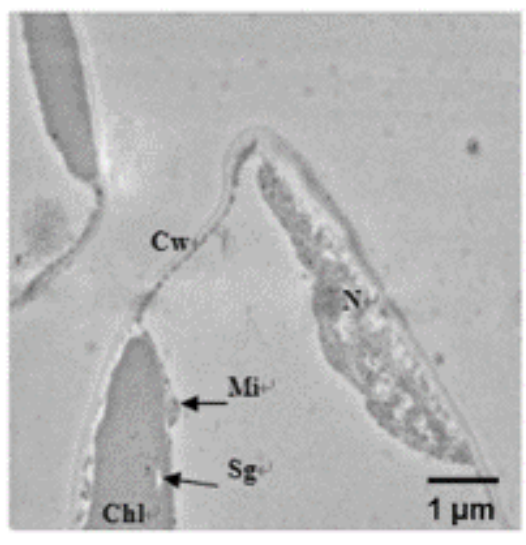

D

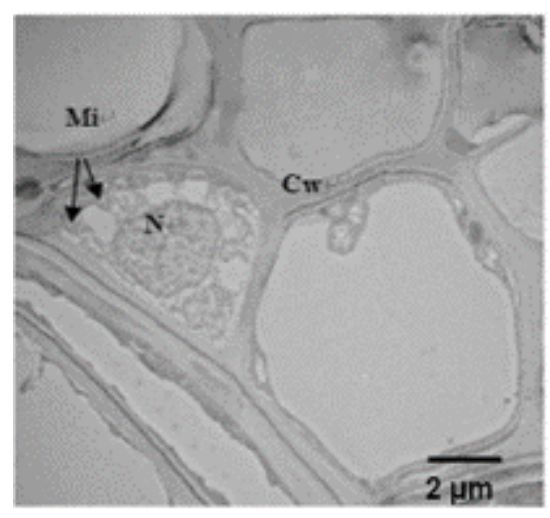

B

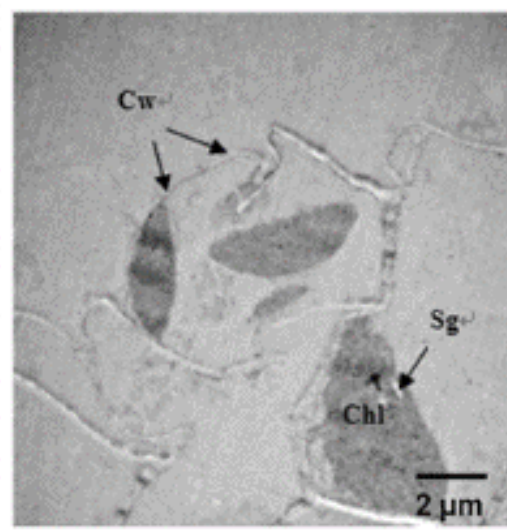

E

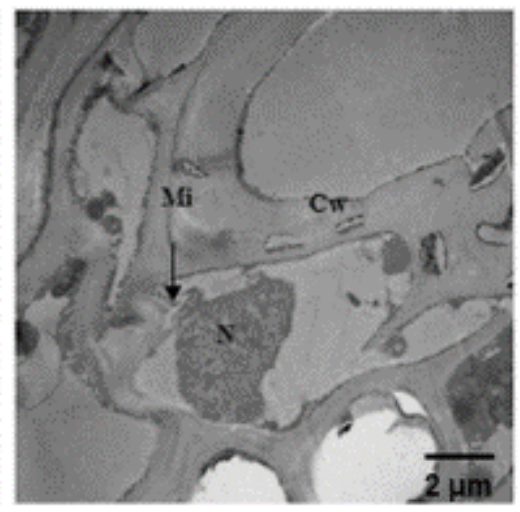

C

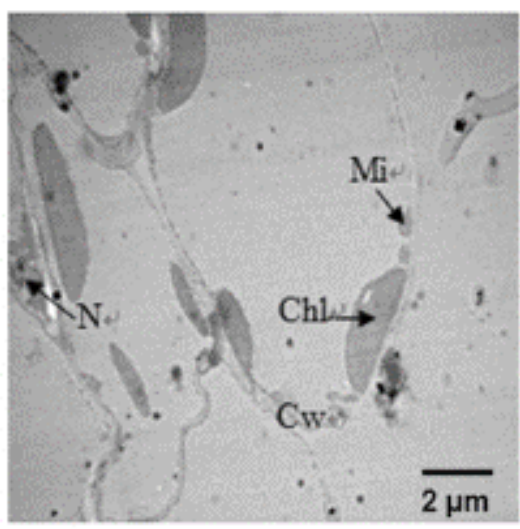

$\mathbf{F}$

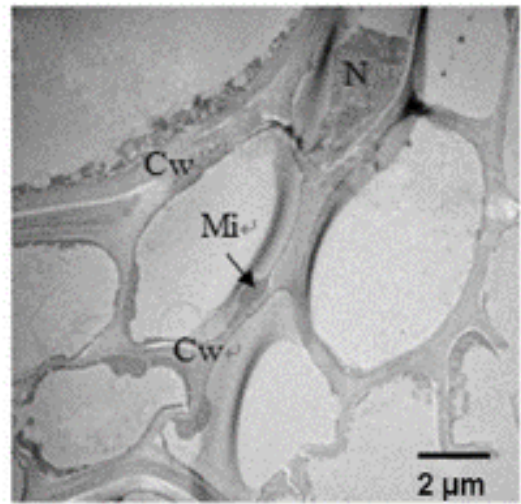

\section{Figure 3}

Observation of cell ultrastructures of perennial ryegrass using transmission electron microscope.(A) The ultrastructure of shoot cells of plants in the soils without addition of uranium; (B) The ultrastructure of shoot cells of plants in the soils with addition of $5 \mathrm{mg} / \mathrm{kg}$ uranium; (C) The ultrastructure of shoot cells ofplants in the soils with addition of $5 \mathrm{mg} / \mathrm{kg}$ uranium and the presence of $5 \mathrm{mmol} / \mathrm{kg}$ citric acid; (D) The ultrastructure of root cells of plants in the soils without addition of uranium; (E) The ultrastructure of root cells of plants in the soils with addition of $5 \mathrm{mg} / \mathrm{kg}$ uranium; (F)The ultrastructure of root cells of plants in the soils with addition of $5 \mathrm{mg} / \mathrm{kg}$ uranium and the presence of $5 \mathrm{mmol} / \mathrm{kg}$ citric acid. Chl, Chloroplast; $\mathrm{CW}$, Cell wall; N, nucleus; Mi, mitochondria; Sg, starch grain. 